\title{
STRUCTURAL AND NEOTECTONIC CRITERIA FOR LOCATION OF WATER WELLS IN SEMI-ARID CRYSTALLINE TERRAINS: A PRELIMINARY APPROACH IN THE EASTERN DOMAIN OF RIO GRANDE DO NORTE STATE, NORTHEAST BRAZIL
}

\author{
ANA CATARINA FERNANDES CORIOLANO, EMANUEL FERRAZ JARDIM DE SÁ \\ AND CARLOS CÉSAR NASCIMENTO DA SILVA
}

\begin{abstract}
The traditional methods to locate water wells in crystalline terranes are being re-evaluated aiming to improve the success rate of the procedures. We describe the preliminary approach being used in the eastern crystalline domain of Rio Grande do Norte (NE Brazil), encompassing areas around Santo Antônio and Santa Cruz cities. Emphasis is given to re-evaluate the classical structural criteria in the light of modern concepts on rock deformation and the regional tectonic framework, especially in the context of the neotectonic stress regime. At a first step, the structural analysis is applied to better understand the formation and/or reactivation of brittle structures, their chronology, and past and present kinematics. Then, these informations are used to understand water flow and accumulation in fracture aquifers, and the reasons for success or failure in the location of water wells already drilled in the region, in the hope to establish a more consistent and practical routine methods. Lineament maps of the studied areas were generated to determine the main fracture sets for well location. Structural data were collected near selected water wells, locally combined with geophysical data. Neotectonic reactivation is evaluated both from regional and local information, as available. In some cases, as in Tararaca Farm near Santo Antônio, a correlation was found between a fracture zone and a photointerpreted lineament following a drainage; the favorable orientation of the fractures, at a high angle to the present (neotectonic) extension direction, appears to convey an important control in water accumulation and well production. In other cases, as in the Santa Rita Farm near Santa Cruz, the photolineament and the drainage do not correspond to a fracture zone; and the accumulation of water is related to the opening of foliation surfaces by weathering, its intersection with different fracture sets and favorable recharge conditions provided by locally thicker, alluvial covers, forming a through-like structure.
\end{abstract}

Keywords: water wells, semi-arid terranes, structural criteria, Northeast Brazil

INTRODUCTION The hinterland of Northeast Brazil, like in the Rio Grande do Norte State, is characterized by a semi-arid climate in extensive areas of crystalline rocks. In this kind of terrain, the best places for drilling water wells generally coincide with narrow and densely fractured zones that may or not be related to major faults. In these zones, the choice of the best sites for drilling, based on the classical approaches of lineament identification in aerial photographs followed by field checking, is a difficult and misleading task, frequently with a low success rate. Aiming to improve the success statistics of these locations, a research program is being undertaken in the eastern domain of the Rio Grande do Norte State, involving areas near the cities of Santo Antônio and Santa Cruz (Fig. 1).

Current location methods are based on structural concepts that date back to the 1950-60 (Costa 1965, Siqueira 1967), which deserve a critical re-evaluation in the light of modern concepts on rock deformation, regional tectonic evolution (emphasizing brittle deformation episodes), and reactivation of different structures under neotectonic stress regimes. The classical methodology does not considers that most fractures in the crystalline basement formed at greater depths and under old stress fields, which differ significantly from to the present, neotectonic regime. The latter probably has a stronger influence in the near-surface conditions for water flow and accumulation than hitherto assumed. Thus, fractures regarded as favorable for water storage (precambrian extension joints, for instance) could nowadays be acting as "closed", if their orientation is at a high angle to the present subhorizontal compressional axis $\left(\sigma_{1}\right.$ or $S_{H}$, as named by neotectonicists and seismologists). In an ideal case, and apart from other required conditions, the best, "open" structures would be those at a high angle to the present extension direction $\left(\sigma_{3}\right.$ or $\left.S_{h}\right)$. This is one of our main assumptions, or working hypotheses, and this paper describes how this analysis is being applied in selected study cases, and how the field context may differ significantly from the simple interpretation frequently assumed from aerial photographs.

\section{REGIONAL GEOLOGIC AND NEOTECTONIC}

FRAMEWORK The study areas are located in the Borborema Province (Almeida et al. 1977), a tectonic domain affected by the Neoproterozoic Brasiliano orogeny. In Rio Grande do Norte, the precambrian rocks (known as the Seridó Belt) comprise a sequence of metasupracrustals (the Seridó Group) and its basement (GneissMigmatite Complex), both intruded by Brasiliano and pre-Brasiliano granitoids.

In NE Brazil, brittle deformation episodes occurred at different times during the Phanerozoic (Jardim de Sá et al. 1999), starting with the uplift, exhumation and cooling of the crust at the end of the Brasiliano orogeny (Neoproterozoic to Cambrian-Ordovician). These processes superimposed a set of low temperature, ductile-brittle or brittle structures, frequently reworking the structures of the preceding, high temperature stage, roughly under the same kinematics (Coriolano et al. 1997). Another major episode is related to the rifting and formation of the continental margin basins, from late JurassicCretaceous to the beginning of the Tertiary (Matos 1992). Based on kinematic markers, mineral fillings and other features, bearing on their approximate PT conditions of formation, the bulk of the fracture network in the crystalline rocks of this region formed during one of these two events.

The tectonic evolution from the late Tertiary to the Holocene is represented by the sedimentary and volcanic deposits, both inland and offshore, and is well preserved in the geomorphologic and morphotectonic evolution, including a crustal scale doming that formed the Borborema Plateau, later subject to present erosion (Saadi 1993, Jardim de Sá et al. 1999). In this context, the best records of the Neogene structural evolution are found in the late Tertiary to Holocene markers and morphotectonic features (Bezerra et al. 1993, Coriolano et al. 1997, Caldas et al. 1997, Dantas 1998), additional to the important seismic activity in the region (Ferreira et al. 1998). Recognition of neotectonic reactivation in the crystalline domain has been reported from a few localities (Coriolano et al. 1997, Menezes and Jardim de Sá 1999).

The seismic activity in NE Brazil, exemplified by the Samambaia Seismic Fault (near João Câmara, Rio Grande do Norte) and many other sites, allows to establish the present stress field as a transcurrent regime with E-W compression $\left(\sigma_{1}\right)$ and $\mathrm{N}-\mathrm{S}$ extension $\left(\sigma_{3}\right)$ axes. This stress field is related to spreading of the Atlantic Ridge and/or to the Andean compression, which are responsible for more localized extensional stresses, perpendicular to the coast, due to the mass unbalance in the continent-ocean transition (Assumpção 1992, Ferreira et al. 1998).

The present stress field justifies our assumption that, whatever their age, steep-dipping, roughly E-W fractures tend to behave as "open", being more favorable for water flow and accumulation, while those roughly N-S tend to be "closed". NE- and NW-trending fractures act as shear surfaces that may be also productive, especially at intersection zones and transtensional sites.

\section{THE STRUCTURAL AND NEOTECTONIC APPROACHES}

The classical method to locate water wells in crystalline rocks involves the interpretation of aerial photographs and examination of outcrops, especially with regard to the "degree of fracturing" of the rocks (Costa 1965, Siqueira 1967). Based on their field characteristics (vein filling, shear indicators), the structures are interpreted in the light of stress fields (and the related crustal depth and environment) which were 


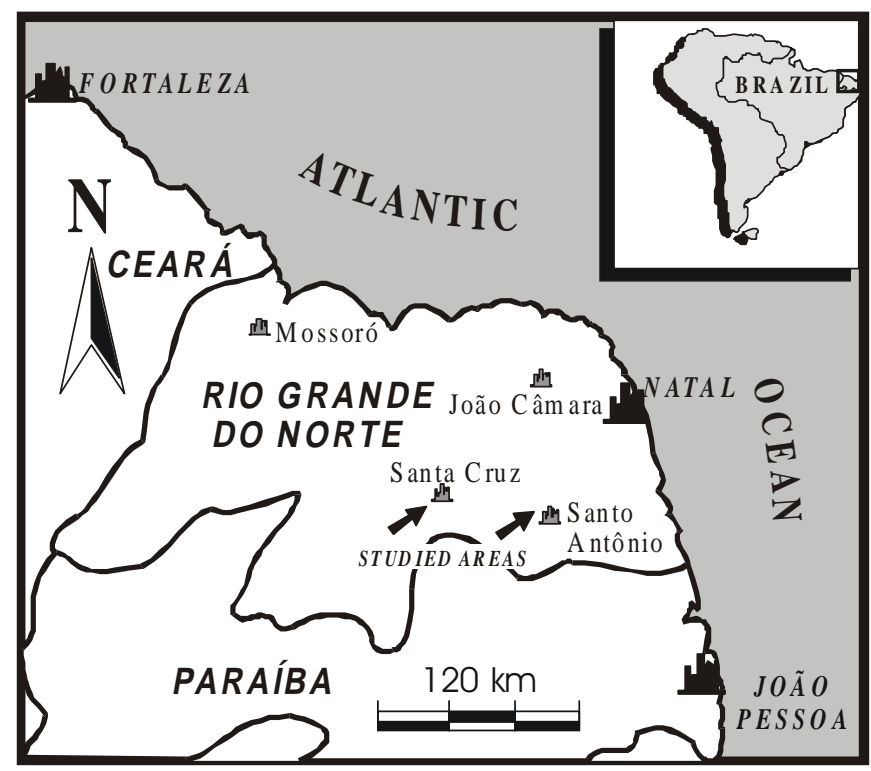

Figure 1-Geographic location of the studied areas.

active at the time of their development, which dates back to Cretaceous or even Cambrian times (Coriolano et al. 1997, Jardim de Sá et al. 1999). Comprehensively, the stress regimes related to these old fractures may have little (or directly, any) relationship with the present dynamic conditioning of groundwater percolation and accumulation in the fractured reservoirs. In this case, the role of the old structures resides in the formation of a high "porosity/permeability" zone, one of the requirements (but not the only) for accumulation of water reserves.

A widely used concept for location of water wells is the riacho-fen$d a$ ("stream-fracture"; Siqueira 1963), that represents the association of the hydrography with geology. It provides the best infiltration conditions and water storage in fractured crystalline rocks. The riachofenda corresponds to the situation in which the drainage coincides with a fracture zone, being recognized in aerial photographs and even in the field, due to the linear segments of a given river channel.

For the present paper, reinterpreted water wells that were located according to the classical approach. Initially, a research of the records from the late Mineral Resources Development Company of Rio Grande do Norte (the CDM/RN) were used as a data base to select areas containing wells that contrast in water production. Unfortunately, the sample population had to be reduced after fieldwork, due to unreliable well data records or to the lack of nearby outcrops.

In the field, fracture sets were characterized style, geometry, chronological relationships, and kinematics, and compared with the photointerpreted lineaments. The kinematics of the fracture sets was assessed through a comparison with the neotectonic and present seismotectonic framework to establish their "open" or "closed" behavior regarding groundwater flow and storage.

The fracture chronology is obtained according to the type of affected markers, vein filling and coating materials, and other related features intersection of different fracture sets and relationships with morphotectonic elements. The youngest fractures identified on such grounds are those that may be related to the neotectonic stress regimes.

CASE STUDIES Two areas, located near Santo Antônio and Santa Cruz cities, were selected to illustrate the complexities eventually involved in what appears, at a first glance, to be simple examples of the riacho-fenda concept. In both cases, the approach began with the interpretation of 1:70,000 scale aerial photographs commonly used for water prospecting in the region, from which lineament maps emphasizing brittle structures were produced. A more sophisticated approach is in course, using TM Landsat images and different treatment procedures.

In Santo Antônio, a water well in the Tararaca Farm, located close to the intersection of two streamlets and near outcrops of "basement" orthogneisses was studied. The well is regarded as unproductive due to its low yield, about $100 \mathrm{l} / \mathrm{h}$.

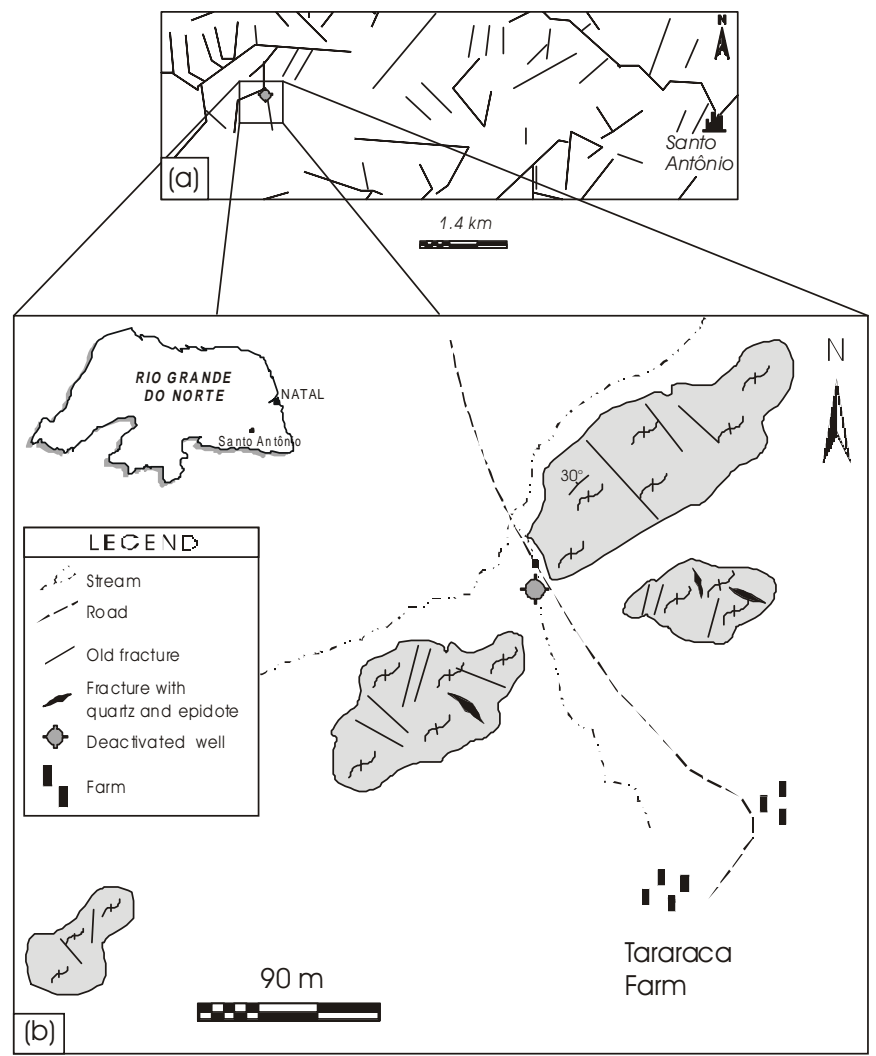

Figure 2-(a) Photolineament map of Santo Antônio region; (b) location of the well, in Tararaca Farm.

In aerial photographs, it is possible to identify a N-S and NEtrending lineaments, both following local riacho-fendas. The well was located near the intersection of these features (Fig. 2a).

In the field, the streams do not have expressive alluvium thickness, especially the one with a N-S direction. Structural analysis of the outcrops determined predominantly NW-trending fractures. NEtrending fractures are not noticeable, although the gneiss foliation locally trends NE, dipping to NW (Fig. 2b). This casts doubt on the application of the riacho-fenda concept to this place. Judging from outcrops, the NE trend of the larger stream seems to be controlled by the rock foliation.

Geophysical data at this site, using VLF (Very Low Frequency) and apparent resistivity (Silva 2000), confirm the presence of a $\mathrm{N}$-trending fracture along the smaller stream. In spite of the well having been located in a fracture zone, its yield is quite low. Therefore, the N-S structure probably corresponds to a closed fracture, what could have been anticipated by its angular relation to the neotectonic stress axes (orthogonal to the E-trending $\sigma_{1}$ or $\mathrm{S}_{\mathrm{H}}$ axes).

Near Santa Cruz City, five wells were drilled in the Santa Rita Farm. Two of them are in operation, two were disabled, and a fifth was dry. The place is once again sited on "basement" orthogneisses, with minor amphibolite bands and cut by metric veins of granite and pegmatite.

The interpretation of aerial photographs identified an ENE-trending lineament that controls the drainage and along which the wells were drilled (Fig. 3a). Here, the riacho-fenda concept was applied once again.

In the field, ENE-trending fractures parallel to the stream were not identified. The fractures are predominantly NW trending (Fig. 3b). The gneiss foliation follows the ENE direction of the stream, dipping about $45^{\circ} \mathrm{S}$. The local drainage controls a small through-like structure. Sandy to clay-rich alluvium is quite thick (up to $3 \mathrm{~m}$ or even more). In outcrops, weathering is intense and "open" the foliation, which is frequently filled with regolith and alluvial sands. The NW-trending fractures interconnect these discontinuities (Fig. 3c).

Geophysical data in the area (Silva 2000) confirm the absence of a major fracture zone along the ENE-trending stream. The field data indicate a though-like structure, with a considerable amount of 

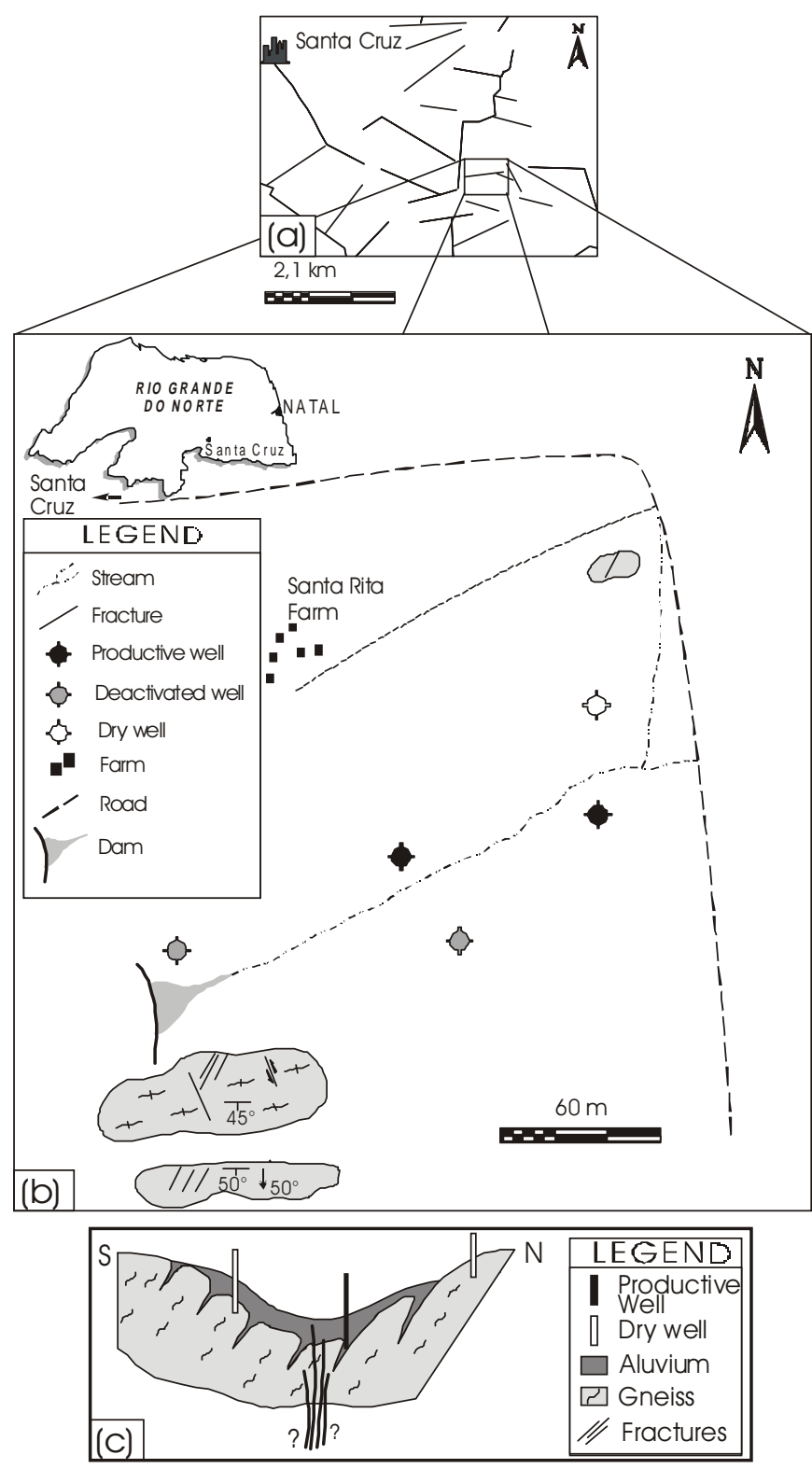

Figure 3- (a) Photolineament map of Santa Cruz region; (b) location of the group the wells, in Santa Rita Farm; (c) schematic section of the through-type model. alluvium and regolith. In this case, the difference between dry and disabled, as compared to productive wells, might be related to the geometry (especially the differential depth) of the structurally controlled weathering surfaces and the thick alluvial and regolith covers that provide adequate recharge conditions. The productive wells probably coincide with places where weathering deepens along the foliation, "opening" it and increasing the rock porosity and permeability.

DISCUSSION These studies illustrate the difficulties arising in the uncritical association of photolineaments to the riacho-fenda concept. Water well location essentially based on this concept may lead to pronounced discrepancies of well yields.

In the studied areas, the photolineaments do coincide with the stream directions (as a consequence of the usual method of interpretation). However, they may not correspond to major or even minor fracture zones. Furthermore, if this coincidence happens, the fracture does not necessarily behave as an open fracture, as reported from the Tararaca Farm, near Santo Antônio. In this case, the neotectonic framework forecasts a low yield potential for a N-trending fracture. The small number of structures along this direction minimizes the potential porosity due to fracture intersections that characterize a fault zone.

In the case of Santa Rita Farm, near Santa Cruz, the stream does not coincide with any fracture structure. The underground water flow and storage appears to be related to the thicker alluvial cover and to the weathering following (and "opening") the rock foliation, increasing its porosity and permeability.

The reported results are preliminary and essentially illustrate the approach adopted in this on going research. Nevertheless, they call attention to the misleading results that may be found in a quick, uncritical application of the riacho-fenda concept and in the correlation of photolineaments and field-scale structures. The assessment of the potential, present "open" or "closed" behavior of fractures (and eventually the control of weathering even along "old", "closed" foliation surfaces) through neotectonic and morphotectonic data seems to be a promising prospect to be tested along this research and by water resources development companies in the region.

Acknowledgments To Jesimael Avelino da Silva, Walter Eugênio de Medeiros (PPGG-UFRN), Waldir Duarte Costa (CAPES Visiting Professor at PPGG-UFRN) and Elmo Marinho Figueiredo (IDEMA and the late State Mineral Development Company - CDM/ $\mathrm{RN}$ ) for helpful discussions. To FINEP/CNPq/PADCT for financial support and fellowships to the authors. To two anonymous referees of RBG for the critical review of the manuscript.

\section{References}

Almeida F. F. M, Hasui Y, Brito Neves B. B., Fuck R. A. 1977. Províncias estruturais brasileiras. In: Simpósio de Geologia do Nordeste, 7, Campina Grande-PB, 363-391. Assumpção M. 1992. The regional intraplate stress field in South America. Journal Geophysical Research. 97:11889-11903.

Bezerra F. H. R., Saadi A., Moreira J. A. M., Lins F. A. P. L., Nogueira A. M. B., Macedo J. W. P., Lucena L. F., Nazaré D. 1993. Estruturacão Neotectônica do Litoral de natal-RN, com Base na Correlação entre Dados Geológicos, Geomorfológicos nat-Re, com Base na Correlaçáo entre Dados Geotóctônicos, 4. Belo Horizonte-MG. Anais, 12:317-321.

Caldas L. H. O., Coriolano A. C. F., Dantas E. P., Jardim de Sá E. F. 1997. Os Beachrocks no Litoral do Rio Grande do Norte: Potencial como Marcadores Neotectônicos. In: Simpósio de Geologia do Nordeste, 17. Fortaleza-CE. Resumos Expandidos, Simpósio de

Coriolano A. C. F., Jardim de Sá E. F., Cowie P. A., Amaral C. A. 1997. Estruturas Frágeis no Substrato da Região de João Câmara (RN): Correlação com a Falha Sísmica de Samambaia? In: Simpósio de Geologia do Nordeste, 17. Fortaleza-CE. Resumos Expandidos, 15:325-329.

Costa W. D. 1965. Análise dos fatores que influenciam na hidrogeologia do cristalino. Água Subterrânea. 4:14-47.

Ferreira J. M., Oliveira R. T., Takeya M. K., Assumpção M. 1998. Superposition of local and regional stresses in northeast Brazil: evidence from focal mechanisms around the Potiguar marginal basin. Geophysics. 134:341-355.
Jardim de Sá E. F., Matos R. M. D., Morais Neto J. M., Saadi A., Pessoa Neto O. C. 1999. Epirogenia Cenozóica na Província Borborema: Síntese e Discussão sobre os Modelos de Deformação Associados. In: Simpósio Nacional de Estudos Neotectônicos

e Simpósio Internacional de Tectônica da SBG, 7. Lençóis-BA. Anais, 58-61.
Matos R. M. D. 1992. The Northeast Brazilian Rifte System. Tectonics. 1:766-791.

Menezes M. R. F. and Jardim de Sá E. F. 1999. Caracterização de Fraturamento Neotectônico em Rochas Cristalinas: o Exemplo da Grota da Fervedeira, Santana do Matos, RN. In: Simpósio Nacional de Estudos Neotectônicos e Simpósio InternaciMatos, RN. In: Simpósio Nacional de Estudos Nectôtoctônica da SBG, 7. Lençóis-BA. Anais, 62 - 66.

Saadi A. 1993. Neotectônica da Plataforma Brasileira; esboço e interpretação preliminar. Geonomos, 1:1-15.

Silva J. A. 2000. Estruturas de acumulação de água em rochas cristalinas: estudo geofísico e geológico de casos no Estado do Rio Grande do Norte. UFRN/CCET/PPGG, Dissertação de Mestrado, (Inédito)

Siqueira L. 1967. Contribuição da Geologia à Pesquisa de água subterrânea no cristalino. Água Subterrânea, 9:1-29. 